\title{
UNIVERSITYOF
}

FORWARD

THINKING

WESTMINSTER用

WestminsterResearch

http://www.westminster.ac.uk/westminsterresearch

\section{"Utopian in the right sense": The Responsibility to Protect and the Logical Necessity of Reform}

Hehir, A.

This journal article has been accepted for publication and will appear in a revised form, subsequent to peer review and/or editorial input by Cambridge University Press in the Ethics and International Affairs.

(C) Cambridge University Press, 2017

The final definitive version in the online edition of the journal article at Cambridge Journals Online is available at:

https://dx.doi.org/10.1017/S0892679417000235

The WestminsterResearch online digital archive at the University of Westminster aims to make the research output of the University available to a wider audience. Copyright and Moral Rights remain with the authors and/or copyright owners.

Whilst further distribution of specific materials from within this archive is forbidden, you may freely distribute the URL of WestminsterResearch: ((http://westminsterresearch.wmin.ac.uk/)).

In case of abuse or copyright appearing without permission e-mail repository@westminster.ac.uk 


\section{UNIVERSITYOF}

FORWARD

THINKING

WESTMINSTER用

WestminsterResearch

http://www.westminster.ac.uk/westminsterresearch

\section{"Utopian in the right sense": The Responsibility to Protect and the Logical Necessity of Reform}

Hehir, A.

This journal article has been accepted for publication and will appear in a revised form, subsequent to peer review and/or editorial input by Cambridge University Press in Ethics and International Affairs.

(C) Cambridge University Press, 2017

The final definitive version in the online edition of the journal article at Cambridge Journals Online will be available at:

http://onlinelibrary.wiley.com/journal/10.1111/(ISSN)1747-7093/

The WestminsterResearch online digital archive at the University of Westminster aims to make the research output of the University available to a wider audience. Copyright and Moral Rights remain with the authors and/or copyright owners.

Whilst further distribution of specific materials from within this archive is forbidden, you may freely distribute the URL of WestminsterResearch: ((http://westminsterresearch.wmin.ac.uk/)).

In case of abuse or copyright appearing without permission e-mail repository@westminster.ac.uk 


\title{
"Utopian in the right sense": The Responsibility to Protect and the Logical
}

\section{Necessity of Reform}

\author{
Aidan Hehir
}

\begin{abstract}
In this article I argue that the claims made about the efficacy of the Responsibility to Protect (RtoP) echo the pejorative conceptions of "utopianism" advanced by E. H. Carr and Ken Booth, in two ways: by virtue of RtoP's supporter's determination to claim "progress" in spite of countervailing empirical evidence, and the exaggerated importance supporters ascribe to institutionalization, which mistakenly conflates state support with a change in state behavior and interests. I argue that RtoP's impact on the behavior of states has been, and will continue to be, limited and that while RtoP has garnered widespread support amongst states, this is due to it having been rendered largely impotent through a process of norm co-optation. While both Carr and Booth criticized a particular form of utopianism, I demonstrate that both also defended the articulation of normative prescriptions that are not immediately feasible; to this end, I conclude by suggesting a potential reform of the existing international legal order that meets Carr's preference for normative thinking that is "utopian in the right sense".
\end{abstract}

\section{INTRODUCTION}

In this article I argue that the claims made about the success of the Responsibility to Protect (RtoP) to date and about its bright future cohere with conceptions of "utopianism" as advanced in particular by E. H. Carr and Ken Booth. Arguments heralding the efficacy of RtoP echo Carr's and Booth's characterizations of utopianism in two ways: a determination to claim "progress" in spite of countervailing empirical evidence, and an exaggeration of the importance of institutionalization that mistakenly conflates state support with a change in state behavior and interests.

RtoP's efficacy is predicated on its capacity to serve as a means by which political and moral pressure is brought to bear on states-particularly the permanent five members of the Security Council (P5)—-so that they take remedial action in order to avoid "social exclusion."1 The strategy underpinning RtoP, therefore, seeks to alter the behavior of states 
through moral advocacy rather than legal reform, which is invariably dismissed by RtoP supporters as impossible to achieve. Therefore, the concept is commonly presented as the best, most realistic option and, ostensibly, "the only show in town for those serious about preventing future Kosovos and future Rwandas."2 While RtoP has certainly become embedded in international political debate, I will argue that its impact on the behavior of states has been limited. To do this, I will analyze the "successes" routinely advanced as evidence of RtoP's efficacy, which, I will demonstrate, do not equate with the empirical evidence relating to human rights protection globally. At the same time, I will highlight what I take to be an analytical bias toward preserving a narrative of "progress." Ironically, while RtoP has garnered widespread support amongst states, this is due to it having been rendered largely impotent through a process of norm co-optation. While RtoP has, therefore, proved more palatable to states than legal reform, it is palatable precisely because it does not compel meaningful change in state behavior.

Given the nature of contemporary events, and specifically the increase in human rights violations and intrastate mass atrocity crimes, I argue that those seeking to ensure that the international community is consistently responsive to intrastate atrocity crimes must embrace the need for legal reform so as to diminish the influence of national interests on decisions regarding when, where, and how to respond. At present, reform may not seem politically possible or imminent, but this does not necessarily render the idea "utopian." While both Carr and Booth criticized a particular form of utopianism, I demonstrate that both also defended the articulation of normative prescriptions that are not immediately feasible. I conclude by offering a potential reform based on these principles.

\section{A Balance Between Utopia ANd Reality}


Within international relations (IR) and international law, the term "utopian" has invariably been applied pejoratively; typically, an idea is "utopian" when the ends sought do not cohere with the existing characteristics, and evolutionary trajectory, of the contemporary political system. ${ }^{3}$ Critiques of "utopianism"—-certainly within IR—often draw on Carr's The Twenty Years' Crisis. Carr critiqued utopianism characterized by aspirational propositions rather than empirical analysis. ${ }^{4}$ Utopians, he argued, based their arguments on so-called "facts" that were actually the product of their own hopes rather than scientific inquiry; as a consequence, the utopian "inhabits a dream world." 5 These utopians, Carr noted, tended to claim progress when elements of their project became institutionalized and rhetorically avowed by states. This was particularly evident, he suggested, with respect to those provisions of the League of Nations' Covenant that enunciated lofty aims—-such as the renunciation of war and the principle of decision-making by consensus — that did not cohere with the existing dispositions of states. Thus, though these ideals were institutionalized in the League's Covenant, they did not change state interests or behavior, but rather were used by states as rhetorical weapons and thus became "bulwark[s] of the status quo."6

While Carr's critique of utopian thinking is widely known, his defense of normative theorizing has often been overlooked. As noted by Booth, some proponents of "doctrinal realism" consciously ignore the nuances of Carr's argument and his "decidedly utopian leanings."7 These scholars espouse a worldview based on a presumption of systemic immutability and perennial power politics, and thus predict "continuity, regularity, and repetition."8 This is a truncated caricature of realism, which is not reflective of Carr's position, or of the strain of normative theorizing that runs through this school of thoughtparticularly classical realism—more generally. ${ }^{9}$ On a closer look, one sees that Carr's critique of utopianism did not in fact constitute a critique of any theory or prescription that aimed to limit the occurrence of war. In fact, he actually criticized those whose views were overly 
fatalistic and singularly focused on state power, and he argued that academia should be normative and focused on "what ought to be." 10 He advocated a "mature" methodological approach situated between the "naivety" of the utopian and the "sterility" of the realist, one that has the ability to advance prescriptions that are not, at present 'wholly attainable'. ${ }^{11}$ Carr's critique was therefore of a particular form of normative theorizing; indeed, he characterized his own vision as utopian. ${ }^{12}$

Drawing on Carr's analysis, Booth advocated a "utopian realism" that navigates between the extremes of both utopianism and realism in an effort to effect positive change. ${ }^{13}$ Though critical of doctrinal realism, Booth argued that those seeking a better world should not lapse into future-orientated musings that ignore the existing dispositions of states, and thus fail to chart a realistic means by which to achieve their ends. ${ }^{14}$ Like Carr's critique of the “hollow" progress of institutionalization, Booth also cautioned against conflating states' stated support for change with actual change in the behavior of states; those who uncritically celebrated the assurances of states, Booth argued, were engaged in "self-deception." 15 Their desperation to maintain the veracity of their progress narrative had in fact turned many advocates of change into "house trained 'critics' of the powerful" who, "always adjust to their ruler's agendas and flatter the power which is ruling."16

Thus, while Carr and Booth's ideological foundations and prescriptions were quite different, their critiques of utopianism clearly overlap; both advocate a realistic utopianism and criticize doctrinal or sterile realists who dismiss all normative prescriptions. Booth's utopian realism is based on an understanding of utopia where the goals sought are "freed from the definitional trap of having to appear immediately possible," 17 while Carr likewise defends the articulation of prescriptions that are not immediately attainable as being "utopian in the right sense." 18 Yet, both are also critical of utopianism that is characterized by teleological zealotry and by a determination to claim success and progress almost solely 
based on what states and their leaders promise. I argue that this understanding of utopian in the pejorative sense characterizes the discourse surrounding the putative success of RtoP.

\section{The Responsibility to Protect}

While the post-cold war era began with widespread optimism about a greater role for the United Nations in the protection of human rights, a series of intrastate atrocities in the 1990s highlighted that the international community remained inconsistently responsive to such crises, in large part because of the powers vested in the P5. ${ }^{19}$ NATO's "illegal but legitimate" 20 intervention in Kosovo in 1999 highlighted the problem most starkly; this evident disjuncture between law and morality was widely lamented, and calls for reform abounded. ${ }^{21}$ In response, in 2001 the International Commission on Intervention and State Sovereignty (ICISS) published its report The Responsibility to Protect.

Rather than challenge the legal rights of states or call for the reform of the international legal architecture, ICISS sought to work within the existing system and explicitly rejected the idea of reform. ${ }^{22}$ Likewise, the version of RtoP endorsed at the 2005 World Summit did not constitute a new law, as is widely accepted by RtoP's key supporters. ${ }^{23}$ RtoP's efficacy, therefore, is not predicated on it having created either a new legal obligation for states, or a new means by which international institutions are mandated to authorize the international response to intrastate crises, or censure states for committing intrastate mass atrocities. Rather, the efficacy of RtoP is predicated on its "Three Pillars" (protection, assistance, and timely response) operating simultaneously to alter the behavior and disposition of states by creating a new normative framework within which states consider how to act appropriately. 
As RtoP seeks to change the disposition of states through force of argument rather than legal censure or compulsion, any purported efficacy is premised on a particular understanding of the role and power of norms ${ }^{24}$ By virtue of constituting a norm, RtoP ostensibly makes it difficult to engage in, or legitimize, certain behavior. ${ }^{25}$ Advocates argue that state affirmations of RtoP constitute "speech acts" 26 that lead to a process of what some have called "rhetorical entrapment" 27 whereby the routine invocation of RtoP by states limits their capacity and willingness to ignore looming or actual mass atrocities internally or elsewhere. Intrastate mass atrocity crimes have clearly been perpetrated since 2005, but proponents of RtoP note that research on norms demonstrates that norm violations do not in themselves constitute evidence that a norm is no longer operable, nor does contestation surrounding the meaning of a norm. ${ }^{28}$ Rather, proponents argue that having now established itself as a norm, RtoP is ostensibly poised to grow in influence, while overcoming occasional lapses in its implementation.

Any hypothetical legal reform that would alter the means by which the international community regulates compliance with human rights law and authorizes remedial measures is invariably deemed impossible and/or undesirable. ${ }^{29}$ The more realistic and viable strategy, so the logic goes, is to work with the existing system and its laws. ${ }^{30}$ Thus, at its core RtoP has a conceptual distinction between what is deemed realistic, namely RtoP, and what is seen as essentially utopian, namely reform of the existing system.

\section{UTOPIANISM AND RTOP}

The arguments of those making the case for RtoP's success and transformative potential cohere with Carr and Booth's characterization of pejorative utopianism in two ways: a determination to claim progress in spite of countervailing empirical evidence, and an 
exaggeration of the importance of a form of institutionalization that mistakenly conflates state support with a change in state behavior and interests.

\section{"Progress" and Evidence}

While proponents of RtoP do not laud it as a silver bullet, central to the narrative heralding its efficacy are claims regarding its progress to date. RtoP has, its supporters claim, made "tremendous progress," 31 and "begun to change the world" 32 by virtue of exercising a definite and growing influence on the behavior of states. Central to the rationale underpinning RtoP is the principle that it "applies everywhere, all the time" and not only after mass atrocities occur. ${ }^{33}$ Indeed, RtoP's primary function, proponents have increasingly argued, is as a means to prevent the occurrence of mass atrocities. ${ }^{34}$ This has led to a plethora of reports, books, and articles advancing prescriptions on how to tackle the root causes of mass atrocities and identify triggers that can lead to them. ${ }^{35}$ Thus, while RtoP explicitly targets the four crimes in the 2005 World Summit Outcome document, it is not limited to situations where these crimes have occurred; the preventative element necessitates eliminating lower-level human rights abuses that are known to lead to the occurrence of one or more of the four crimes. A recent Tweet from Alex Bellamy is representative of this logic: "Preventing atrocity crimes starts with ending all forms of discrimination."36

Yet, since 2014 a series of reports from a wide array of UN bodies, human rights organizations, and think tanks—-such as the UN High Commissioner for Refugees, Human Rights Watch, Amnesty International, the International Crisis Group, Freedom House, the Uppsala Conflict Data Program, and the International Committee of the Red Cross- have all recorded a dramatic increase in crimes against humanity, genocide/politicide, and state oppression, while noting a concomitant growing unwillingness on the part of the international community to respond in a coordinated, consistent, and effective way. ${ }^{37}$ Amnesty 
International's 2016 report declared the present situation to be the "nadir" in post-World War II human rights protection. ${ }^{38}$ Likewise, Secretary-General Ban Ki-moon noted in his 2016 report on RtoP that the international community had "fallen woefully short" in protecting human rights, and that the "frequency and scale of atrocity crimes have increased." 39

These negative trends are exemplified by the steady deterioration of the crisis in Syria, where bitter divisions among the P5 have rendered them incapable of implementing a coordinated remedial strategy—which, according to the UN High Commissioner for Human Rights, has cost hundreds of thousands of lives. ${ }^{40}$ Russia and China have repeatedly vetoed draft resolutions seeking to impose modest sanctions on Assad's regime, prompting Ban Kimoon to declare that the Security Council had "too often failed to live up to its global responsibility." ${ }^{41}$ In addition to Syria, since 2014 intrastate crises have erupted or escalated in Burundi, the Central African Republic, the Democratic Republic of the Congo, Iraq, Israel, Kenya, Libya, Myanmar, Nigeria, North Korea, South Sudan, Sudan, and Yemen. ${ }^{42}$ The link between civil war, systemic state-sponsored human rights violations, and the four crimes within RtoP's purview is widely recognized; as noted by the Group of Friends of RtoP, "Widespread and systematic abuses or violations of human rights often serve as early warning signs of potential genocide, war crimes, ethnic cleansing and/or crimes against humanity." 43 The increase in state oppression, the sharp deterioration in global respect for human rights, and the growing unwillingness and/or inability on the part of UN member states to respond in a timely, consistent, and effective manner are trends that do not meet the tenets of a normative preventative culture. This suggests that the narrative heralding the “progress" made by RtoP echoes Carr's depiction of the utopian's propensity to ignore facts in favor of an account of progress which, '... was as different from anything they saw around them as gold from lead'. ${ }^{4}$ 


\section{Institutionalization}

Central to RtoP's narrative of success and progress is the fact that since its recognition in 2005 it has garnered widespread state support. RtoP has been routinely affirmed, and very rarely unequivocally disavowed, by states at the General Assembly debates on RtoP held annually since $2009 .{ }^{45}$ Additionally, fifty-six states have now appointed an "RtoP Focal Point”, forty-nine states (and the European Union) have joined the Group of Friends of the Responsibility to Protect, and the Security Council has invoked RtoP in fifty-three resolutions; this is regularly offered as evidence of RtoP's growing power. ${ }^{46}$

The claim—routinely made by proponents of RtoP—that consensus and widespread rhetorical invocation constitute grounds for determining the existence of a norm, $i$ s reflected in the broader literature on norms ${ }^{47}$ Yet, while RtoP may well meet the general criteria for recognition as a norm, this does not necessarily mean it has had, or will have, a positive impact on the behavior of states. That a norm exists does not necessarily constitute a value judgement about its effectiveness, but rather simply establishes that this particular term/phrase/idea commands a degree of consensus and is widely used. ${ }^{48}$ Proponents of RtoP's efficacy, however, often advance an understanding of norms that obscures the spectrum of norm typology, variations in norm efficacy, the complex process by which norms are diffused and implemented, and the influence of power asymmetries on the evolution of norms. ${ }^{49}$ Many of those who advance the success/progress narrative thus engage in a superficial reading of RtoP's evolution. That it has become a norm and that this norm is widely employed is taken as sufficient grounds upon which to base the "progress" claims. In fact, the emergence and later proliferation of a norm need not necessarily constitute a positive development, as is noted below with respect to the Security Council's increased use of RtoP. Norms evidence divergent efficacy and a range of characteristics. A particularly important distinction exists between "regulative" and "constitutive" norms, with the latter 
deemed to create new interests rather than just outline appropriate behavior. ${ }^{50}$ Furthermore, rather than changing existing state interests, a norm can be co-opted, namely applied to legitimize action to further preexisting interests. ${ }^{51}$ Therefore, while the goals behind the emergence of a norm may be laudable, the establishment of that norm does not necessarily mean it will have the intended positive influences on state behavior; in fact, the emergence of a norm may well have a negative impact if it is sufficiently vague so as to be vulnerable to strategic, and indeed mendacious, manipulation. ${ }^{52}$

RtoP certainly constitutes a vague norm; in practice, while states are evidently keen to affirm their commitment to it, there are significant differences among states as to what it actually is. As Jennifer Welsh accepts, "It cannot be assumed that the meaning of a norm such as RtoP is stable, or that it signifies the same thing to all actors postinstitutionalization." 53 While many of those who believe in RtoP's transformative potential do acknowledge the limitations of norms,${ }^{54}$ the efficacy of RtoP is predicated on its progressive evolution, the idea being that while RtoP may not as yet exercise sufficiently powerful leverage against states, it will do so in the future. ${ }^{55}$ Yet the evolutionary trajectory of the RtoP norm to date suggests otherwise.

Security Council resolutions that refer to RtoP evidence a very clear and arguably retrogressive trend. Of the fifty-three resolutions passed that refer to RtoP, only five even acknowledge the existence of Pillar III, the external responsibility of the international community. The rest refer to RtoP only in the context of the host state's responsibility. This indicates, therefore, that the Security Council employs RtoP exclusively to affirm that the responsibility for resolving a particular crisis is not theirs, but rather that of the host state. RtoP is thus being used as a means by which the Security Council evades responsibility. RtoP was not established to better enable the Security Council to justify their own inaction by 
deflecting responsibility on to others, and thus this manifestation of RtoP's increased usage in international discourse actually constitutes a negative development in the norm's evolution.

Leaving the Security Council aside for a moment, the affirmation of RtoP by individual states has two characteristics that should also temper the conflation of increased invocation with progress. First, paragraphs 138 and 139 of the 2005 World Summit Outcome document have been interpreted by a bloc of predominantly developing world states to reiterate the principles of sovereign inviolability and sovereign equality, and to enhance the primacy of the state in protecting its citizens and resolving intrastate crises. These states have, as Welsh notes, employed RtoP so as to preserve "legal egalitarianism"; that is, to enhance the power of the state at the expense of the external regulation of compliance with international human rights law. ${ }^{56}$ Second, these states use the concept to bolster their view that the interventionist role of the international community should be operationalized only with state consent; in this way, RtoP is invoked only in the context of Pillars I and II and the "responsibility to prevent." 57 This restriction of the meaning of RtoP explains the growing consensus and is not necessarily illustrative of a new disposition among previously oppressive states. For many states, therefore, these affirmations of RtoP appear to be strategic signals sent to gain social capital at the UN and to encourage the norm to evolve in a way that supports a preexisting preference for sovereign inviolability. ${ }^{58}$

The actual implementation of a constitutive global norm depends on how it is incorporated into the ideational, material, and institutional structures within each state. If these structures are not altered, then the norm cannot be said to have transitioned from being a regulative norm into an embedded constitutive norm. ${ }^{59}$ Expressing rhetorical support for RtoP does not necessitate a change in the state's "organizational culture," which norm scholars identify as crucial to the efficacy of a norm. ${ }^{60}$ Thus, in practice, states that have expressed a commitment to RtoP have not always institutionalized this commitment; in fact, 
many states have agreed to endorse the principle precisely because it was not viewed as transformational in any way. ${ }^{61}$

As evidence of the above, states such as Bahrain and Sudan, which routinely and actively engage in systematic human rights violations, have expressed their commitment to RtoP. ${ }^{62}$ Additionally, the lack of any membership criteria and the self-regulation of compliance have meant that certain states with very poor human rights records—such as Angola, the Democratic Republic of Congo, and Qatar-have joined the RtoP Focal Points group while continuing to engage in systemic oppression domestically.

The above has shown that the RtoP norm has suffered cooptation. ${ }^{63}$ Its frequent invocation is not a consequence of RtoP having changed the behavior of states but rather a function of its malleability. Thus we see that both the lack of hard evidence supporting RtoP's impact and the conflation of institutionalization with changes to states' interests conforms neatly to both Carr's and Booth's critiques of utopianism. RtoP is not, of course, the first phrase or norm to be cynically invoked; indeed, the long history of norm cooptation should temper the enthusiasm surrounding the perceived significance of RtoP's increased invocation. ${ }^{64}$

\section{THE LOGICAL NECESSITY OF REFORM}

History shows that states will develop an interest in violating a norm if they perceive that it is necessary to do so in order to realize more pressing interests. ${ }^{65}$ The extent to which states violate a norm or law is, of course, dependent on the nature of the punitive redress they face for so doing; preventing and/or halting mass atrocity crimes, therefore, necessitates engaging with the logic behind both the decision to commit such acts and the decision-making calculus faced by those called upon to react to such acts committed outside their territory. 
The decision to commit mass atrocities is invariably a function of a particular set of triggering factors whereby the aggressors perceive that their status, or very existence, is threatened; thus, though the costs associated with committing these crimes may be great, the costs of inaction are considered to be greater. ${ }^{66}$ The decision to engage in mass atrocities is, therefore, always rational—-though obviously immoral—in the sense that it stems from a cost/benefit calculation; authorities who order mass atrocities do not do so inadvertently, but rather on the presumption that, on balance, these acts will strengthen their position. ${ }^{67}$

Because it is a regulative norm, and not a law, RtoP is dependent on the power of shaming to deter or compel behavior. ${ }^{68}$ However, without having meaningfully internalized RtoP, and with Pillar III essentially dormant, ${ }^{69}$ states most likely to engage in mass atrocities - those with histories of repressive rule and an ambivalence toward international opinion—are highly unlikely to view shaming as a sufficiently powerful countervailing disincentive, especially if they (correctly or not) perceive their very existence to be threatened.

RtoP is, therefore, ineffective in precisely those cases where it is needed most; so long as support for RtoP is exclusively for Pillars I and II, the concept will be impotent in cases where engaging in mass atrocity crimes is perceived of as a matter of existential gravity, as is usually the case. ${ }^{70}$ The absence of support for Pillar III undermines the idea that RtoP is making progress, as it is this aspect of RtoP alone that can potentially change the cost/benefit calculations of states likely to engage in intrastate atrocities.

The logic of interests and of a cost/benefit calculation also applies to those called upon to prevent or halt mass atrocities; the external dimension of RtoP is oriented toward the delineation of a positive duty that by definition competes with other norms and imperatives. ${ }^{71}$ History amply demonstrates that states will not take action to prevent or halt mass atrocities in another state if the costs associated with such action-including financial cost, loss of life, 
trade relations with the oppressor state, hostility amongst domestic publics toward intervention, the nature of the oppressor state's allies, and domestic support for the oppressor regime—are too high. ${ }^{72}$ In recent years Western states—invariably the drivers of intervention-have become ever more risk-averse. ${ }^{73}$ So long as those called upon to prevent or halt mass atrocity crimes have a right to act rather than an obligation, the decision to act will by definition stem from such calculations; and as RtoP does not significantly raise the costs of inaction, the calculation is naturally heavily tipped toward not taking inherently costly action. It is not that states seek at all times to avoid taking action that incurs costs, but rather that the determining factor is the balance between the perceived importance of the action and the likely costs associated with it. The efficacy of the RtoP norm is, therefore, prey to the more general cost/benefit analysis that determines state behavior in a system with weak, highly politicized legal bodies. ${ }^{74}$

An analysis of the nature of the problem that impelled the emergence of RtoP-and the fate of the concept since its recognition in 2005-highlights the need to change the existing cost/benefit calculations of states through legal reform. In terms of those states contemplating engaging in mass atrocities, more consistent and automatic punishments for committing such acts would naturally raise the cost of so doing to a more prohibitively high level. Likewise, more consistent and effective international responses to looming or actual mass atrocities require actors with defined duties to respond, as well as punishments for dereliction of those duties. Given that the Security Council was purposely designed to ensure that the power and interests of the Great Powers have institutional expression, it is manifestly not capable of imparting consistent, objective, and ultimately effective punishment. ${ }^{75}$

\footnotetext{
"Utopian in the Right Sense”?
} 
Initiating reform is, of course, a huge challenge. Many scholars, however, have advanced ideas on how to change the existing system $;{ }^{76}$ and while each idea cannot be said to have achieved the balance between utopianism and fatalism advocated by Carr and Booth (and indeed others ${ }^{77}$ ), they all align with the two principles underlying those thinkers' perspectives: that positive change cannot occur if the existing system remains unaltered, and that advancing proposals for a reformed system that are not likely to be accepted at the moment does not render them utopian in the pejorative sense. ${ }^{78}$

The limitations of international law, specifically with respect to law enforcement, have long been noted and lamented. ${ }^{79}$ As Hans Kelsen argued, the UN system established in 1945 is "primitive" precisely because it ensures that political interests determine how and when the law is enforced. ${ }^{80}$ International law, like all law, is inherently political, and those who have called for legal reform that diminishes the influence of politics on law enforcement have generally eschewed overly-ambitious prescriptions that seek to eliminate politics from law altogether, preferring incremental reform that, though difficult to implement, is not impossible to achieve. Indicatively, Kelsen argued that to move the international legal order beyond its primitive stage, greater authority has to be delegated to trans-state institutions. And while he accepted this was inherently difficult, it was, he argued, "not a logical impossibility." 81

Carr's own emphasis on the importance of law on the evolution toward a less violent world, both domestically and internationally, align with this preference for legal change. ${ }^{82}$ Carr noted, however, that the mere existence of law is insufficient; law's efficacy demands "effective machinery," namely, institutions designed both to objectively regulate compliance with the law and ultimately, when necessary, punish violations. ${ }^{83}$ There is, he argued, a fundamental need for a "combination of consent and coercion" to underpin any effective legal order. ${ }^{84}$ At the international level, this requires, he argued, an institution with a global 
remit and coercive capacity. Yet, in keeping with his preference for being "utopian in the right sense," Carr advocated a progressive evolution rather than what he called "muddle headed plans" for a global governance regime. ${ }^{85}$ Booth likewise rejected expansive plans for global governance, advocating instead "reformist steps" toward both the diffusion of decision-making on certain issues to communities below the level of the state, and the transfer of authority on other matters of global importance to "global functional organisations" above the state. ${ }^{86}$

Carr and Booth's prescriptions thus share core similarities: a disinclination to accept that the lawless power politics of the state system is immutable; a belief that normative prescriptions must be advanced lest we lapse into sterility; a conviction that prescriptions need not be immediately feasible, but also should not be hopelessly idealistic; and, ultimately, that progressive change requires diminishing the power of states through the delegation of authority to bodies above_-and in Booth's case also below—states. How might such guidelines be applied to the prevention and cessation of intrastate mass atrocities? Naturally, outlining a detailed plan is beyond the scope of this article, but it is possible, I believe, to determine the principles, and indeed the contours, of a proposal that is "utopian in the right sense."

In terms of principles, if RtoP has failed because it has not significantly altered the cost/benefit analysis of those states most likely to engage in mass atrocity crimes, then any more useful prescription must seek to redress this shortcoming by advancing a form of censure that states will perceive as significant. Likewise, the means by which a state incurs such censure must involve the delegation of authority to a nonstate body. It must be remembered that there are currently means by which intrastate mass atrocity crimes can be prevented and halted, but that they are in practice flawed because they are authorized by an inherently political state-based body, namely the Security Council. 
Mindful of Carr and Booth's warnings regarding overly ambitious plans, any prescription based on these principles should not seek to advocate a theoretically robust but hopelessly unfeasible set of reforms. Rather, the goal should be to design a prescription that, though ambitious, seeks to incrementally establish the permissibility of a particular modus operandi that can serve as a basis upon which more developed structures can be built at a later date.

Having established these principles, the form of censure and the nature of the body delegated to impose it require clarification. Before suggesting one possible reform, it is important to note that there are many potential reforms that can be advanced on the basis of these underlying principles. What follows, then, is not offered as the only viable means by which to initiate the process. Indeed, this idea may be flawed in other ways. However, unless we accept that the system is immutable — and thus reject the analysis presented by Carr, Booth, and others - it must be possible to determine some means by which to catalyze incremental change. This can only happen if sterility and fatalism are rejected and people are willing to articulate an array of proposals. In other words, identifying a realistic means by which to initiate reform cannot happen if the very idea of reform is deemed impossible.

One prescription based on these principles_-and navigating the path advocated by Carr and Booth-would be to argue for a change to Article 6 of the UN Charter, which states that "a Member of the United Nations which has persistently violated the Principles contained in the present Charter may be expelled from the Organization by the General Assembly upon the recommendation of the Security Council." This provision establishes that UN membership is not a right, and thus can be revoked if a state repeatedly acts against the principles outlined in Chapter I of the Charter. The problem with this provision, however, is that expulsion requires, first, a recommendation from the Security Council and, second, the support of the General Assembly. To date, Article 6 has never been triggered. 
If this article were changed to enable a body other than the Security Council to make a recommendation to the General Assembly, however, then this provision would have considerably more teeth. Relating this back to the issue of intrastate mass atrocity crimes, if the authority to propose expulsion of a member state were delegated to the UN secretarygeneral, then it would be much more likely that Article 6 could be triggered. To make such a change less controversial, Article 6 could be interpreted as providing for suspension of membership — as per Article 5 of the Charter-rather than outright expulsion; thus a state could have its membership suspended for a year with the possibility of readmission if the original violations had ceased.

The specter of suspension/expulsion authorized by an impartial body on the basis of intrastate mass atrocity crimes would undoubtedly enter the calculus of states, given that UN membership is clearly something they value. No state has ever permanently withdrawn from the UN; Indonesia did leave in January 1965, but its self-imposed isolation only lasted until September 1966, when it asked to be readmitted. In 1974, apartheid South Africa was expelled from the General Assembly, though not officially from the UN itself, as Article 6 was not invoked due to the Security Council's refusal to support expulsion; and thereafter the South African government repeatedly sought to have the decision revoked. Additionally, upon declaring independence, states are always strikingly eager to join the world organization.

The benefits of such a reform are that it would, albeit minimally, transfer some power to the Secretariat, and thus constitute a tentative step toward the idea of transferring the authority to censure states to a nonstate body. Of course, this would not be a silver bullet; some states may calculate that in certain situations UN membership is a price worth paying. Likewise, there is no guarantee that a recommendation from the secretary-general would be adopted by a two-thirds majority of the General Assembly. Additionally, a high degree of 
prudence would need to be exercised by the secretary-general; proposing the expulsion of one of the P5 would naturally trigger a constitutional crisis for the UN. Such prudence would, however, by definition perpetuate a degree of selectivity. Additionally, and more obviously, such a change would-like all UN reforms-require the consent of the P5, and their appetite for reform has always been, and remains, minimal.

Nonetheless, it is worth noting four aspects of this proposal that increase its appeal when compared with other suggested reforms. First, this change would not in any way diminish the P5's core powers, namely, their veto and their monopoly over the authorization of the use of force. Second, that states can be suspended or expelled from the UN is already an established legal principle. Third, "encouraging respect for human rights" is noted in Chapter I of the Charter as one of the UN's principles, and Security Council practice since the end of the cold war has routinely established that intrastate mass atrocities are recognized as a violation of the UN's principles. Thus, linking the permissibility of suspension or expulsion and the impermissibility of perpetrating intrastate mass atrocity crimes constitutes a union of existing principles rather than a new revolutionary one. Fourth, any fear that such reform would imbue the UN secretary-general with too much power could be mitigated by providing that his or her recommendation would require, for example, the support of the UN High Commissioner for Human Rights and a selection of members from the human rights treaty bodies. In addition, the recommendation would, as per Article 6, also require the assent of the General Assembly, and states would therefore continue to have a role in the process.

While these facts make the proposal more likely to be accepted than many proposals that more overtly challenge the P5 and established principles, there is of course no doubt that objections would be raised, particularly by the P5. Yet, as both Carr and Booth argue, the very point of normative thinking is to advance prescriptions that may not as yet be politically possible, but are also not inherently impossible to achieve. As such, once we accept the 
principle that meaningful proposals for reform challenge the status quo, it is simply stating the obvious to argue that the reforms disturb the existing order and may not be universally welcomed. In discussing the need for international regulatory bodies, Carr argued that these "elegant superstructures" could only be built incrementally after "some progress has been made in digging the foundations." ${ }^{87}$ By virtue of dismissing the need for reform and legal change, RtoP has had little impact on developing these essential foundations. Advancing prescriptions that rebrand existing policies and procedures but do not in any way alter the status quo may result in acquiescence but not in actual change. And by definition not changing a flawed system does not improve the situation, regardless of how enthusiastically the existing powerholders greet the hollow proposals.

\section{CONCLUSION}

RtoP ostensibly works because it is a norm that increasingly frames how states respond to looming or actual mass atrocities; and by virtue of being a norm, as opposed to a proposal for legal or institutional change, it is more palatable to states. In this article I have argued that RtoP's goals are not necessarily pejoratively utopian, but the means advocated are. Expecting revolutionary change in the behavior of states-a change that has no precedent in human history_while advocating the maintenance of the systemic status quo renders the project akin to the utopianism criticized by Carr and Booth.

RtoP's efficacy is "ultimately . . . all about political will," 88 and thus premised on the notion that states will be influenced by the arguments advanced by "good people" 89 who encourage them to behave better. Yet, as Carr noted, the League of Nations floundered because it, too, was premised on the idea that states would be influenced by "world public opinion." 90 Claims regarding RtoP's progress can only be sustained by minimizing the 
importance of, or completely ignoring, countervailing empirical evidence and exaggerating the importance of rhetorical support for RtoP among states.

While RtoP is palatable to states, this palatability is a function of the fact that states can express support for RtoP without having to implement meaningful change in their behavior. The process by which RtoP has come to be a norm routinely avowed by states but only, crucially, in a particular way, fits a broader pattern whereby certain norms are manipulated to further selfish ends. ${ }^{91}$ In practice, the evidence overwhelmingly points towards a sharp and continuing degeneration in global respect for human rights and an increase in mass atrocity crimes. RtoP's continued affirmation of the systemic status quo is therefore untenable. The quest to end mass atrocity crimes requires as a logical necessity proposals for legal and institutional reform that compels rather than merely encourages states to change their behavior. This necessitates the articulation of prescriptions for legal reform that may well be unlikely to occur at present or soon, but that are ultimately more consistent with the underlying logic of the goals sought.

\section{NOTES}

\footnotetext{
${ }^{1}$ Alex Bellamy (2015) The Responsibility to Protect: A Defense (Oxford: Oxford University Press), p. 61

2 Alex Bellamy (2006) 'The Responsibility to Protect after the 2005 World Summit', Policy Brief No. 1, Carnegie Council on Ethics and International Affairs, p. 15

${ }^{3}$ John Mearsheimer (2005) 'E.H. Carr vs. Idealism: The Battle Rages On', International Affairs, 19/2, p. 140. See also, Martti Koskenniemi (2005) From Apology to Utopia (Cambridge: Cambridge University Press), p. 17

${ }^{4}$ E. H. Carr (2001) The Twenty Years' Crisis (Hampshire: Palgrave), p. 7

5 Ibid, p. 13

${ }^{6}$ Ibid, p. 208

${ }^{7}$ Ken Booth (1991) 'Security in Anarchy: Utopian Realism in Theory and Practice', International Affairs, 67/3, p. 531
} 
${ }^{8}$ Christopher Layne (1994) 'Kant or Cant: The Myth of the Democratic Peace', International Security, 19/2, p. 11

${ }^{9}$ Robert Jackson (2006) 'The Safety of the People is the Supreme Law: Beyond Hobbes but not as far as Kant' in William Bain (ed.) The Empire of Security and the Safety of the People (London: Routledge); Anne Peters (2009) 'Humanity as the $A$ and $\Omega$ of Sovereignty', The European Journal of International Law, 20/3, p. 519; Sean Molloy (2006) The Hidden History of Realism (Basingstoke and New York: Palgrave Macmillan); Michael Williams (2007) Realism Reconsidered (Oxford: Oxford University Press); Richard Ned Lebow (2003) The Tragic Vision of Politics (Cambridge: Cambridge University Press); Murielle Cozette (2008) 'Reclaiming the Critical Dimension of Realism', Review of International Studies, 34/1, 5-27

${ }^{10}$ Carr, The Twenty Years' Crisis, p. 6

${ }^{11}$ Ibid, pp. 10-12, p. 202.

${ }^{12}$ Ibid, p. 219

${ }^{13}$ Ken Booth, 'Security in Anarchy: Utopian Realism in Theory and Practice', p. 534

${ }^{14}$ Ibid, p. 536

${ }^{15}$ Ken Booth, (1994) 'Human Wrongs and International Relations', International Affairs, 71/1, p. 104

${ }^{16}$ Ibid, p. 109

${ }^{17}$ Ken Booth, 'Security in Anarchy: Utopian Realism in Theory and Practice', p. 535

${ }^{18}$ Carr, The Twenty Years Crisis, p. 202

${ }^{19}$ Mats Berdal (2003) 'The UN Security Council: Ineffective but Indispensable', Survival, 45/2, p. 9; Allan Buchanan and Robert Keohane (2011) 'Precommitment Regimes for Intervention: Supplementing the Security Council', Ethics \& International Affairs, 25/1, p. 51; Simon Chesterman (2003) 'Hard Cases Make Bad Law' in Anthony Lang, (ed.) Just Intervention (Washington D.C., Georgetown University Press), p. 54

${ }^{20}$ Independent International Commission on Kosovo (2000) Kosovo Report (Oxford: Oxford University Press), p. 4

${ }^{21}$ Paul Christopher (2004) The Ethics of War and Peace (Upper Saddle River: Prentice Hall), p. 248; Stephen Kinloch-Pichat (2004) A UN Legion: Between Utopia and Reality (London: Routledge); Peter Langille (2002) 'Bridging the Commitment-Capacity Gap', The Centre for UN Reform Education, New York; Sir Arthur Watts (2001) 'The Importance of International Law' in Michael Byers (ed.) The Role of International Law in International Politics (Oxford: OUP); Mohammed Ayoob (2002) 'Humanitarian Intervention and State Sovereignty' The International Journal of Human Rights, 6/1, pp. 81-102

${ }^{22}$ Alex Bellamy (2008) Responsibility to Protect: The Global Effort to End Mass Atrocities, (London: Polity), p. 63; Carsten Stahn (2007) 'Responsibility to Protect: Political Rhetoric or Emerging Legal Norm?', American Journal of International Law, 101/1, p.117

${ }^{23}$ The Stanley Foundation (2015) 'The Responsibility to Protect at Ten: Perspectives and Opportunities', November, p. 1 http://www.stanleyfoundation.org/resources.cfm?id=1581; Ban Ki-Moon (2009) 'Implementing the Responsibility to Protect', UN Secretary General Report, A/63/677, 12 January, http://responsibilitytoprotect.org/implementing\%20the\%20rtop.pdf, p. 2; Bellamy, The Responsibility to Protect: A Defense, p. 15; Jennifer Welsh (2006) 'Conclusion: The Evolution of Humanitarian Intervention 
in International Society' in Jennifer Welsh (ed) Humanitarian Intervention and International Relations (Oxford: Oxford University Press), p. 210

${ }^{24}$ Bellamy, The Responsibility to Protect: A Defense, p. 72; Luke Glanville (2016) 'Does RtoP matter? Interpreting the impact of a norm', Cooperation and Conflict, 51/2: pp. 184-199; Jennifer Welsh (2014) 'Implementing the Responsibility to Protect: Catalyzing Debate and Building Capacity', in Alexander Betts and Phil Orchard (eds) Implementation and World Politics: How International Norms Change Politics (Oxford: Oxford University Press), p. 125; Tim Dunne and Katherine Gelber (2014) 'Arguing Matters: The Responsibility to Protect and the Case of Libya', Global Responsibility to Protect, 6/3: pp. 326-349; Cristina Badescu and Thomas Weiss (2010) 'Misrepresenting RtoP and Advancing Norms: An Alternative Spiral?', International Studies Perspectives, 11/4: pp. 354-374

${ }^{25}$ Gareth Evans (2008) The Responsibility to Protect: Ending Mass Atrocity Crimes Once and For All, (Washington DC: Brookings Institution Press), p. 241; Samantha Power (2009) 'Foreword', in Richard Cooper and Juliette Kohler (eds) Responsibility to Protect: The Global Moral Compact for the 21st Century (Hampshire and New York: Palgrave Macmillan); Tim Dunne and Jess Gifkins (2011) 'Libya and the State of Intervention', Australian Journal of International Affairs, 65/5: pp. 515-529; Luke Glanville (2011) 'The Antecedents of "Sovereignty as Responsibility", European Journal of International Relations, 17/2: pp. 233-255; Alex Bellamy (2015) 'The Responsibility to Protect Turns Ten', Ethics \& International Affairs, 29/2, pp. 61-185

${ }^{26}$ Alex Bellamy (2010) 'Kosovo and the Advent of Sovereignty as Responsibility', in Aidan Hehir (ed) Kosovo, Intervention and Statebuilding (London: Routledge), p. 159

${ }^{27}$ Glanville, 'Does RtoP matter? Interpreting the impact of a norm', p. 185; see also Dunne and Gelber, 'Arguing Matters: The Responsibility to Protect and the Case of Libya', pp. 326-349

${ }^{28}$ Bellamy, The Responsibility to Protect: A Defense, p. 61; Welsh, "Norm Contestation and the Responsibility to Protect," p. 395; Alexander Betts and Phil Orchard (2014) 'Introduction: The Normative Institutionalization-Implementation Gap', in Betts and Orchard (eds) Implementation and World Politics: How International Norms Change Politics, p. 1; Thomas Weiss (2014) 'Military Humanitarianism: Syria hasn't killed it', The Washington Quarterly, 37/1; Welsh, "Norm Contestation and the Responsibility to Protect,” p. 383; Glanville, 'Does RtoP matter? Interpreting the impact of a norm', pp. 184-199

${ }^{29}$ A number of scholars have argued that UN reform would benefit RtoP, such as Heather Roff (2013) Global Justice, Kant and the Responsibility to Protect: A Provisional Duty (London: Routledge); Thomas Weiss (2009) What's Wrong with the United Nations and How to Fix It (Cambridge: Polity); and Annie Herro (2014) UN Emergency Peace Service and the Responsibility to Protect (Abingdon: Routledge). This is not reflected, however, in the official status, or agenda, of RtoP. None among the 2001 ICISS report, the 2005 World Summit Outcome Document, the UN secretary-general's annual reports on RtoP, or the goals of RtoP's most prominent think tanks/coalitions—-such as the Global Centre for RtoP, the International Coalition for RtoP, or the Asia Pacific Centre for RtoP-advocate for UN reform.

${ }^{30}$ Evans, The Responsibility to Protect, p. 137; Sara Davies and Alex Bellamy (2014) 'Don't be Too Quick to Condemn the UN Security Council Power of Veto', E-International Relations, August 12, https://theconversation.com/dont-be-too-quick-to-condemn-the-un-security-council-power-of-veto-29980; 
Bellamy, The Responsibility to Protect: A Defense, p. 11; Global Centre for RtoP (2009) 'Frequently Made Assertions', June 16, Available online,

http://globalr2p.org/media/pdf/Frequently_made_assertions_16_June_Final.pdf, p. 3; Glanville, 'Does RtoP matter? Interpreting the impact of a norm', 184-199; Edward Luck (2010) 'The Responsibility to Protect:

Growing Pains or Early Promise?', Ethics \& International Affairs, 24/4: 349-365; Simon Adams (2015)

'RtoP at Ten', E-International Relations, March 29th, http://www.e-ir.info/2015/03/29/r2p-at-10/

${ }^{31}$ Simon Adams (2015) 'The Responsibility to Protect: Ten Years On', OpenCanada, May 8, https://www.opencanada.org/features/the-responsibility-to-protect-10-years-on/

${ }^{32}$ Bellamy, The Responsibility to Protect: A Defense, p. 111

${ }^{33}$ Alex Bellamy (2014) 'The Responsibility to Protect and the 2014 Conflict in Gaza', E-International Relations, July 22, http://www.e-ir.info/2014/07/22/the-responsibility-to-protect-and-the-2014-conflict-ingaza/

${ }^{34}$ Evans, 'From an Idea to an International Norm', p. 79; Bellamy, Responsibility to Protect: The Global Effort to End Mass Atrocities, p. 3

35 Office of the Special Adviser on the Prevention of Genocide (2014) 'Framework of Analysis for Atrocity Crimes: A Tool for Prevention'; Ban Ki-Moon (2010). Early Warning, Assessment and the Responsibility to Protect (A/64/864); Ban Ki-Moon (2013). Responsibility to Protect: State Responsibility and Prevention (A/67/929); Serena K. Sharma and Jennifer Welsh (eds) (2015) The Responsibility to Prevent (Oxford: Oxford University Press)

${ }^{36}$ Alex Bellamy (2016) Tweet, 29 February, https://twitter.com/Alex_J_Bellamy/status/704449981806043137?lang=en-gb

${ }^{37}$ UNHCR (2015) 'World at War: UNHCR Global Trends', http://unhcr.org/556725e69.html, pp 3-5; Human Rights Watch (2015) World Report 2015, www.hrw.org/sites/default/files/wr2015_web.pdf, p. 1; Amnesty International (2015) 'Annual Report 2014/2015', https://www.amnesty.org/en/latest/research/2015/02/annual-report-201415/; Jean-Marie Guéhenno (2015) 'The World's fragmenting Conflicts', International Crisis Group: The Future of Conflict, October 26, https://medium.com/the-future-of-conflict/the-world-s-fragmenting-conflicts-7d9c2eac98d6; Freedom House (2016) 'Freedom in the World', https://freedomhouse.org/report/freedom-world-2016/overview-essayanxious-dictators-wavering-democracies; Uppsala Conflict Data program (2015) 'Organized Violence in the World 2015', http://www.pcr.uu.se/digitalAssets/61/61335_1ucdp-paper-9.pdf, p. 1; International Committee of the Red Cross (2015) 'World at a Turning Point: Heads of UN and Red Cross issue joint warning', 30 October, https://www.icrc.org/en/document/conflict-disaster-crisis-UN-red-cross-issue-warning

38 Amnesty International (2016) 'Amnesty International 2015/16: The State of the World's Human Rights', https://www.amnesty.org/en/latest/research/2016/02/annual-report-201516/, p. 15

${ }^{39}$ Ban Ki-moon (2016) 'Mobilizing Collective Action: The Next Decade of the Responsibility to Protect', Report of the Secretary-General, A/70/999-S/2016/620, $22^{\text {nd }}$ July, p. 3

${ }^{40}$ Navi Pillay (2014) 'UN Human Rights Chief Criticises UN over Global Conflicts', The Guardian, August 22, www.theguardian.com/world/2014/aug/22/un-human-rights-chief-criticises-security-council-over-globalconflicts 
${ }^{41}$ Ban Ki-Moon (2015) 'A Vital and Enduring Commitment: Implementing the Responsibility to Protect', UN Secretary General Report, A/69/981, 13, July, p. 13

42 Ibid, p. 3

43 Group of Friends of the Responsibility to Protect (2016) 'Statement by the Group of Friends of the Responsibility to Protect in Geneva at the HRC 33 General Debate Item 10 - Technical assistance and capacity-building', 28 September, http://www.globalr2p.org/media/files/gof-hrc33-statement-on-technicalassistance-and-capacity-building.pdf

,p. 7

45 Gareth Evans (2016) 'RtoP: The Next Ten Years' in Alex Bellamy and Tim Dunne (eds) Oxford Handbook of the Responsibility to Protect (Oxford: Oxford University Press), p. 2; Adams, 'RtoP at Ten'; Ban KiMoon, 'A Vital and Enduring Commitment: Implementing the Responsibility to Protect'; Jess Gifkins (2016) 'RtoP in the UN Security Council: Darfur, Libya and beyond', Cooperation and Conflict, 51/2, pp. 148-165; Global Public Policy Institute (2015) 'Effective and Responsible Protection from Atrocity Crimes: Towards Global Action', Policy April, http://www.globalnorms.net/fileadmin/user_upload/Publications/GlobalNorms_2015_Effective_and_Respon sible_RtoP.pdf

${ }^{46}$ Global Centre for RtoP (2017) 'RtoP Focal Points', http://www.globalr2p.org/our_work/global_network_of_r2p_focal_points; Group of Friends of the Responsibility to Protect (2016) 'Statement by the Group of Friends of the Responsibility to Protect in Geneva at the Informal Interactive Dialogue with Under-Secretary-General Mr. Adama Dieng, Special Adviser to Secretary-General on the Prevention of Genocide', 3 March, http://www.responsibilitytoprotect.org/Group\%20of\%20Friends\%20of\%20RtoP\%20(Denmark).pdf; Global Centre for RtoP (2017) 'UN Security Council Resolutions Referencing RtoP', http://www.globalr2p.org/resources/335; Gifkins, 'RtoP in the UN Security Council: Darfur, Libya and Beyond'; Adams, 'The Responsibility to Protect: Ten Years On'; Bellamy, The Responsibility to Protect: A Defense, p. 26; Dunne and Gelber, 'Arguing Matters: The Responsibility to Protect and the Case of Libya', pp. 326-349; Glanville, 'Does RtoP matter? Interpreting the Impact of a Norm', pp. 184-199; Global Public Policy Institute (2015) 'Effective and Responsible Protection from Atrocity Crimes: Towards Global Action', Policy Paper, April, http://www.globalnorms.net/fileadmin/user_upload/Publications/GlobalNorms_2015_Effective_and_Respon sible_RtoP.pdf, p. 3; Weiss, 'Military Humanitarianism: Syria hasn't killed it', p. 10

${ }^{47}$ Martha Finnemore and Sikkink, Kathryn (1998) 'International Norm Dynamics and Political Change', International Organizations, 52/4: 895; Betts and Orchard, 'Introduction: The Normative Institutionalization-Implementation Gap', p. 1; Mona Lena Krook and Jacqui True (2010) 'Rethinking the Life Cycles of International Norms: The United Nations and the Global Promotion of Gender Equality', European Journal of International Relations, 18/1: p. 106

48 Jeffrey Legro (1997) 'Which Norms Matter?' International Organisation, 51/1, p. 34

${ }^{49}$ Amitav Acharya (2013) 'The RtoP and Norm Diffusion: Towards a Framework of Norm Circulation', Global Responsibility to Protect, 5/1: 466-479; Krook and True, 'Rethinking the Life Cycles of International 
Norms: The United Nations and the Global Promotion of Gender Equality', p.108; Jeffrey Checkel (1999)

'Norms, Institutions, and National Identity in Contemporary Europe', International Studies Quarterly, 43/1:

83-114; Wayne Sandholtz (2008) 'Dynamics of International Norm Change', European Journal of International Relations, 14/1: p. 103; Shareen Hertel (2006) Unexpected Power (Ithaca, NY: Cornell University Press)

${ }^{50}$ Finnemore and Sikkink, 'International Norm Dynamics and Political Change', p. 891; Alexander Wendt (1999) A Social Theory of International Politics (Cambridge: Cambridge University Press), p. 92; Peter Katzenstein (1996) 'Introduction: Alternative Perspectives on National Security', in Peter Katzenstein (ed) The Culture of National Security (New York: Columbia Press); Audie Klotz (1995) 'Norms Reconstituting Interests: Global Racial Equality and US Sanctions Against South Africa’, International Organization, 49/3, pp. 451-478

${ }^{51}$ Betts and Orchard, 'Introduction: The Normative Institutionalization-Implementation Gap', p. 16

${ }^{52}$ Diana Panke and Ulrich Petersohn (2011) 'Why International Norms Disappear Sometimes' European Journal of International Relations, 18/4, pp. 724-5

${ }^{53}$ Welsh, "Norm Contestation and the Responsibility to Protect," p. 380

${ }^{54}$ Bellamy, The Responsibility to Protect: A Defense, p. 61; Betts and Orchard, 'Introduction: The Normative Institutionalization-Implementation Gap'

55 Theresa Chataway (2007) 'Towards Normative Consensus on Responsibility to Protect', Griffith Law Review, 16/1, pp.193-224; Evans, 'RtoP: The Next Ten Years'; Adams, 'The Responsibility to Protect: Ten Years On'; Badescu and Weiss, 'Misrepresenting RtoP and Advancing Norms: An Alternative Spiral?', pp. 354374

${ }^{56}$ Welsh, 'Norm Contestation and the Responsibility to Protect', p. 394

${ }^{57}$ Patrick Quinton-Brown (2013) 'Mapping Dissent: The Responsibility to Protect and its State Critics', Global Responsibility to Protect, 5/3, pp. 260-282; Adrian Gallagher (2015) 'The Promise of Pillar II: Analysing International Assistance Under The Responsibility to Protect', International Affairs, 91:6, pp. 1259-1275

${ }^{58}$ Amitav Acharya (2011) 'Norm subsidiarity and Regional Orders: Sovereignty, Regionalism, and Rulemaking in the Third World', International Studies Quarterly, 55/1, p. 96; Emmanuel Adler and Vincent Pouliot (2011) 'International Practices', International Theory, 3/1, p. 17; KM Fierke (2002) 'Links across the Abyss: Language and Logic in International Relations', International Studies Quarterly, 46/3, p. 331354; Paul Kowert and Jeffrey Legro (1996) 'Norms, Identity and Their Limits', in Peter Katzenstein (ed) The Culture of National Security (New York: Columbia Press), p. 484

${ }^{59}$ Betts and Orchard, 'Introduction: The Normative Institutionalization-Implementation Gap', p.12

${ }^{60}$ Legro, 'Which Norms Matter?', p. 33

${ }^{61}$ Welsh, "Norm Contestation and the Responsibility to Protect," 373

${ }^{62}$ Bahrain (2012) 'Statement of the Kingdom of Bahrain at the Sixty-Seventh Session of the UN General Assembly', 27 September, http://gadebate.un.org/sites/default/files/gastatements/67/BH_en.pdf; Sudan (2009) 'Statement by Sudan on the Protection of Civilians in Armed Conflict' Wednesday, 11 November 2009, http://responsibilitytoprotect.org/Sudan(1).pdf

${ }^{63}$ Jack L.Goldsmith, and Eric A. Posner (2002) 'Introduction', Journal of Legal Studies, XXXI: 104 
${ }^{64}$ Krook and True, 'Rethinking the Life Cycles of International Norms: The United Nations and the Global Promotion of Gender Equality', p. 104; Antje Wiener (2008) The Invisible Constitution of Politics. Contested Norms and International Encounters (Cambridge: Cambridge University Press)

65 Panke and Petersohn, 'Why International Norms Disappear Sometimes', p. 734

${ }^{66}$ Office of the Special Adviser on the Prevention of Genocide (2014) 'Framework of Analysis for Atrocity Crimes: A Tool for Prevention', http://www.un.org/en/preventgenocide/adviser/pdf/framework\%20of\%20analysis\%20for\%20atrocity\%20cri mes_en.pdf, p. 17; Bellamy, The Responsibility to Protect: A Defense, p. 23

${ }^{67}$ Michael Howard (1984) The Causes of War and Other Essays (Cambridge MA: Harvard University Press), pp. 14-15; Zygmunt Bauman (1989) Modernity and the Holocaust (Ithaca: Cornell University Press); Michael Mann (2005) The Dark Side of Democracy (Cambridge: Cambridge University Press); Philip Zimbardo (2007) The Lucifer Effect: How Good People Turn Evil (London: Random House). This does not mean these acts were defensible or even strategically logical. Rather, that they were impelled by a sense of existential crisis that convinced those responsible to commit these acts. The decisions were taken "rationally" in the sense that they were the result of a cost/benefit calculation; the information used to make the cost/benefit calculations may well have been, of course, wholly inaccurate; see, Charles Glaser (2010) Rational Theory of International Politics: The Logic of Competition and Cooperation (Princeton, NJ: Princeton Press), p. 3; Robert Keohane (2002) 'Rational Choice Theory and International Law: Insights and Limitations', Journal of Legal Studies, XXXI, p. 308.

${ }^{68}$ Gareth Evans (2015) 'RtoP: Looking Back, Looking Forward', Keynote Address, Phnom Penh, Cambodia, 26 February 2015, http://www.gevans.org/speeches/speech568.html

69 Justin Morris (2013) 'Libya and Syria: RtoP and the Spectre of the Swinging Pendulum', International Affairs, 89/5, pp. 1265-1283; Adrian Gallagher (2015) 'The Responsibility to Protect Ten Years on from the World Summit: A Call to Manage Expectations', Global Responsibility to Protect, 7/3; Roland Paris (2014) 'The "Responsibility to Protect" and the Structural Problems of Preventative Humanitarian Intervention', International Peacekeeping 21/5: 1-35

${ }^{70}$ Examples since RtoP was recognised in 2005 include the Sudanese repression in Darfur, the Sri Lankan government's campaign against the Tamil Tigers in 2009, the Assad regime's “counterterrorism” strategy since 2012, the Bahrain monarchy’s repression in 2011, and the conflict in Burundi since 2014.

${ }^{71}$ Martha Finnemore (2008) 'Paradoxes in Humanitarian Intervention' in Richard Price (ed) Moral Limit and Possibility in World Politics (Cambridge: Cambridge University Press)

72 Simon Chesterman (2006) 'Humanitarian Intervention and Afghanistan', in Jennifer Welsh (ed) Humanitarian Intervention and International Relations (Oxford: Oxford University Press), p. 163; Nicholas Wheeler and Justin Morris (2007) 'Justifying the Iraq War as a Humanitarian Intervention: The Cure is Worse than the Disease', in Ramesh Thakur and W. P. S. Sidhu (eds) The Iraq Crisis and World Order: Structural, Institutional and Normative Challenges (New York: United Nations University Press); James Pattison (2010) Humanitarian Intervention and the Responsibility to Protect (Oxford: Oxford University Press), p. 110; Alan Bloomfield (2016) 'Norm Antipreneurs and Theorising Resistance to Normative Change', Review of International Studies, 42/2, p. 325 
${ }^{73}$ Jonathan Gilmore (2015) The Cosmopolitan Military: Armed Forces and Human Security in the $21^{\text {st }}$ Century (Hampshire: Palgrave MacMillan), pp. 181-182

${ }^{74}$ Goldsmith and Posner (2002) 'Introduction', Journal of Legal Studies, XXXI: S2; George Downs and Michael Jones (2002) 'Reputation, Compliance, and International Law’, Journal of Legal Studies, XXXI, p. 105

75 Nigel White (2004) 'The Will and Authority of the Security Council after Iraq', Leiden Journal of International Law, 17/4, p. 666; Antonio Cassese (2005) International Law (Oxford: Oxford University Press), p. 319; Ian Hurd (2007) After Anarchy (Princeton NJ: Princeton University Press), p. 191; David Bosco (2009) Five to Rule Them All (Oxford: Oxford University Press), p. 10; Dimitri Bourantonis (2007) The History and Politics of Security Council Reform (London: Routledge), p. 6

${ }^{76}$ Weiss, What's Wrong With the United Nations and How to Fix It, p. 180; Jean Cohen (2004) 'Whose Sovereignty? Empire Versus International Law', Ethics \& International Affairs, 18/3, p. 3; Buchanan and Keohane, 'Precommitment Regimes for Intervention: Supplementing the Security Council', pp. 41-63; Pattison, Humanitarian Intervention and the Responsibility to Protect; Anthony Lang and Aidan Hehir (2015) 'The Impact of the Security Council on the Efficacy of the International Criminal Court and the Responsibility to Protect', Criminal Law Forum, 26/1, pp. 153-179

${ }^{77}$ Richard Wyn Jones (2005) ‘On Emancipation: Necessity, Capacity and Concrete Utopias’, in Ken Booth (ed) Critical Security Studies and World Politics (London: Lynne Rienner)

${ }^{78}$ Carr, The Twenty Years Crisis, p. 202

${ }^{79}$ Louis Henkin (1990) ‘Compliance with International Law in an Inter-State System’, Academie de droit international, Recueil des cours 1989 (Dordrecht: Martinus Nijhoff); Peters, 'Humanity as the A and $\Omega$ of Sovereignty', pp. 513-544; Cherif Bassiouni (2009) 'Advancing the Responsibility to Protect Through International Criminal Justice', in R.H. Cooper and J.V. Kohler (eds.) Responsibility to Protect: The Global Moral Compact for the $21^{\text {st }}$ Century (Hampshire and New York: Palgrave Macmillan); Monica Hakimi (2010) 'State Bystander Responsibility', The European Journal of International Law, 21/2, pp. 341-385; Martti Koskenniemi (2006) 'What is International Law For?' in Mark Evans (ed.) International Law (Oxford: Oxford University Press)

${ }^{80}$ Hans Kelsen (1945) General Theory of Law and State (Cambridge MA: Harvard University Press), p. 338

${ }^{81}$ Hans Kelsen (1972) Peace Through Law (Cambridge MA: Harvard University Press), p. 40

${ }^{82}$ Carr, The Twenty Years Crisis, p. 166

${ }^{83}$ Ibid, p. 176

${ }^{84}$ Ibid, p. 193

${ }^{85}$ Ibid, p. 202

${ }^{86}$ Ken Booth, 'Security in Anarchy: Utopian Realism in Theory and Practice', p. 536 \& 541

${ }^{87}$ Carr, The Twenty Years Crisis, p. 219

${ }^{88}$ Edward Luck (2010) 'The Responsibility to Protect: Growing Pains or Early Promise?', Ethics \& International Affairs, 24/4, pp. 349-365

${ }^{89}$ Evans, The Responsibility to Protect, p. 7

${ }^{90}$ Carr, The Twenty Years Crisis, p. 193 
${ }^{91}$ Kowert and Legro, 'Norms, Identity and Their Limits', p. 493 